\title{
FAKTOR KELUARGA, MEDIA, DAN TEMAN DALAM PEMILIHAN MAKANAN PADA MAHASISWA PPKU IPB
}

\author{
Laras Aulia ${ }^{*}$, Lilik Noor Yuliati \\ Departemen IImu Keluarga dan Konsumen, Fakultas Ekologi Manusia, Institut Pertanian Bogor, \\ Bogor 16680, Indonesia
}

*)Email:aulia_laras@yahoo.co.id

\begin{abstract}
Abstrak
Penelitian ini bertujuan untuk menganalisis pengaruh faktor keluarga, media, dan teman terhadap pemilihan makanan. Faktor keluarga dinilai dari gaya pengasuhan dan pola komunikasi orang tua sedangkan faktor media dan teman dinilai dari paparan informasi yang diperoleh mahasiswa. Desain penelitian ini menggunakan metode survei kuantitatif. Data dikumpulkan secara self-administered yang melibatkan 288 mahasiswa tingkat pertama yang dipilih dengan teknik cluster random sampling. Data dianalisis menggunakan analisis deskriptif, uji beda, dan uji regresi linear berganda. Hasil penelitian menunjukkan bahwa terdapat perubahan kebiasaan makan sayur mahasiswa sebelum dan setelah masuk IPB. Sebelum masuk IPB, mahasiswa laki-laki cenderung makan sayur dengan porsi setengah mangkok, sedangkan pada mahasiswa perempuan makan sayur dengan porsi satu mangkok. Hasil penelitian juga menemukan bahwa hampir seluruh mahasiswa baik laki-laki maupun perempuan dibesarkan dengan gaya pengasuhan otoritatif oleh orang tuanya. Hasil penelitian ini menunjukan bahwa lebih dari tiga perempat mahasiswa laki-laki dan perempuan mempunyai tipe pola komunikasi conversation orientation dengan orang tuanya. Mahasiswa laki-laki dan perempuan cenderung terpapar informasi melalui media dibandingkan oleh teman. Hasil penelitian ini tidak menemukan adanya perbedaan paparan informasi melalui media dan teman antara laki-laki dan perempuan. Penelitian ini menemukan tiga alasan utama dalam pemilihan makanan khususnya sayur pada mahasiswa yaitu kesehatan, suasana hati, dan pengendalian berat badan. Hasil uji regresi linear berganda menunjukan bahwa pemilihan makan sayur pada mahasiswa dipengaruhi oleh gaya pengasuhan otoritatif yang diterima mahasiswa dari orang tuanya, paparan informasi dari media, dan jenis kelamin.
\end{abstract}

Kata kunci: informasi media, informasi teman, gaya pengasuhan, pola komunikasi keluarga, pemilihan makanan.

The Influence of Family, Media, and Peer Factors on Food Choices among of PPKU IPB

\begin{abstract}
This study aimed to analyze the influence of family factors media and friends on college student's food choice specifically vegetables. Family factors are assessed from parenting style and parent communication patterns while media and friend factors are judged from the exposure of information obtained by the students. Design of this study was using a quantitative survey. Data were collected by self-administered involving 288 first-year students selected by cluster random sampling. Data were analyzed using descriptive analysis, a different test, and multiple linear regression test. The results showed there was a change in eating habits of students before and after IPB. Before entering the IPB male students tend to eat vegetables with half a bowl serving, while the female students eat vegetables with a serving of one bowl. Almost all student parenting styles applied by parents of male and female students are authoritative parenting style. The results of this study show that more than threequarters of male and female students have a type of communication pattern of conversation orientation. Male and female students tend to be exposed to information through the media rather than by friends. There is no difference in the exposure of information through media and friends between men and women. This study found three main reasons for the selection of food, especially vegetables in the students of health, mood, and weight control. The results of multiple linear regression test showed that the selection of eating vegetables in students influenced by authoritative parenting style, media, and gender.
\end{abstract}

Key words: family communication pattern, food choice, parenting style, socialization

\section{PENDAHULUAN}

Pemilihan makanan merupakan bagian proses dalam memilih makanan untuk dikonsumsi dari hasil pengaruh persaingan, penguatan, dan interaksi berbagai faktor. Menurut Steptoe et al. (1995) faktor-faktor mendasari memilih makanan yaitu kesehatan, suasana hati, kenyamanan, sensorik, kandungan alami dalam pangan, harga, pengendalian berat badan, familiaritas, dan masalah etika. Faktor yang memengaruhi pemilihan makanan 
seseorang mencakup faktor biologi, psikologi, sosial budaya, ekonomi dan lingkungan. Faktor yang signifikan terhadap proses seleksi makanan adalah faktor biologi. Selain perspektif biologi, terdapat faktor lain seperti kebutuhan energi dan preferensi terhadap rasa (Sommer et al., 2012). Hasil penelitian Lyte et al. (2000) menyebutkan adanya perubahan memilih makanan pada masa anak-anak ke remaja seperti penurunan konsumsi sayur dan buah serta peningkatan konsumsi makanan instan. Ree et al. (2008) menunjukkan sekitar 70 persen remaja memilih makanan tanpa memperhatikan masalah kesehatan, dengan alasan lebih cenderung karena memperhatikan pengendalian berat badan. Penelitian Septiani (2014) di salah satu wilayah di Indonesia menemukan bahwa remaja di perkotaan dan pedesaan mengalami obesitas dan cenderung suka mengonsumsi makanan siap saji. Berbagai jenis makanan siap saji yang sering dikonsumsi remaja, khususnya pada waktu sore hari, diantaranya fried chicken, pizza, spaghetti, dan burger (Hadi, 2005).

Keluarga dijadikan mahasiswa yang sebagai kelompok acuannya, sehingga cenderung berpeluang untuk memiliki kebiasaan makan tiga kali sehari, makan malam, dan makan camilan (Saufika, Retnaningsih, \& Alfiasari, 2012). Pembentukan pemilihan makanan dalam keluarga dilakukan melalui proses sosialisasi yang terjadi dari sejak lahir. Hasil penelitian tersebut mengindikasikan bahwa faktor keluarga memberikan andil dalam membentuk selera dan keinginan yang berbeda-beda pada seseorang dalam pemilihan makanan, termasuk remaja yang menginjak dewasa seperti mahasiswa.

Mahasiswa merupakan bagian pada kategori tahap remaja akhir dan dewasa awal yaitu berusia 18-24 tahun. Pada tahap ini merupakan tahap pertama individu memutuskan jenis makanan sendiri (Perera \& Madhujith, 2012). Mahasiswa memiliki karakteristik dan berasal dari berbagai daerah sehingga memiliki perilaku serta kebiasaan yang berbeda. Mahasiswa tingkat pertama berada pada tahap adaptasi untuk mengadopsi perilaku makan sehat ataupun tidak sehat. Jenis makanan yang seimbang sehingga dapat memenuhi seluruh kebutuhan gizi bagi tubuh dan mampu dirasakan secara fisik dan mental disebut makanan sehat. Perilaku makan sehat merupakan perilaku mengonsumsi berbagai jenis kelompok makanan, salah satunya sayur. Sayur menjadi menu yang hampir selalu ada dalam hidangan sehari-hari keluarga Indonesia, baik sayur dalam bentuk mentah (lalapan segar) atau setelah diolah menjadi berbagai macam bentuk masakan. Konsumsi sayur secara teratur dapat bermanfaat untuk melindungi tubuh dari berbagai penyakit seperti penyakit jantung koroner, hipertensi, dan kanker (British Dietetic Association, 2011). Data Badan Ketahanan Pangan Daerah (BKPD) Provinsi Jawa Barat pada tahun 2015 menunjukkan bahwa Indonesia berada pada tingkat konsumsi sayur di bawah standar FAO dalam mencukupi kebutuhan gizi masyarakat. Standar konsumsi sayur di Indonesia minimal 200 gr/orang/hari, sedangkan anjuran konsumsi sayur menurut WHO setiap orang mengonsumsi buah dan sayur sebanyak 400 gr/hari setara dengan 2-4 porsi buah dan 3-5 porsi sayur. Namun, konsumsi buah dan sayur masyarakat Indonesia berkisar 2,5 porsi per hari dan ditemukan sebanyak 93,8 persen remaja usia 15-24 tahun kurang mengonsumsi sayuran. Hal inilah yang menjadi alasan menarik bagi penelitian ini untuk mengkaji pemilihan makanan pada mahasiswa khususnya dalam konsumsi sayur, mengingat manfaat sayur dan konsumsinya yang masih rendah.

Pola perilaku mengonsumsi makanan tidak sehat dapat diubah dengan pengaruh lingkungan keluarga yang mendukung. Pemilihan makanan dapat dipengaruhi melalui sosialisasi. Sosialisasi bagian proses memperoleh pengetahuan, keahlian, dan hubungan sosial agar mampu berpartisipasi sebagai anggota masyarakat (Sumarwan, 2011). Menurut Hawkins et al. (2002) sosialisasi konsumen adalah proses orang muda (dari lahir hingga 18 tahun) belajar untuk menjadi konsumen. Sosialisasi konsumen akan mendapatkan pengetahuan tentang barang dan jasa serta pengetahuan konsumsi dan pencarian informasi serta keterampilan untuk menawar barang dan jasa. Menurut Mowen dan Minor (1998) tiga unsur utama dari sosialisasi konsumen yaitu faktor latar belakang konsumen, pihak yang melakukan sosialisasi terhadap konsumen, dan proses belajar yang dialami konsumen. Sumarwan (2011) menyatakan bahwa faktor latar belakang terdiri dari karakteristik konsumen seperti status sosial ekonomi, jenis kelamin, usia, kelas sosial, dan agama. Faktor yang melakukan sosialisasi adalah seseorang yang secara langsung berhubungan dengan konsumen dan memiliki pengaruh terhadap konsumen, seperti orang tua, saudara, teman, guru, dan media massa. Selanjutnya, faktor yang melakukan sosialisasi tersebut akan memengaruhi proses belajar konsumen 
melalui proses belajar modelling, penguatan, dan kognitif. Proses sosialisasi anak menjadi konsumen dipengaruhi oleh beberapa faktor salah satunya umur yang merupakan indikator penting dalam perkembangan fisik dan kognitif anak. Menurut Hawkins et al. (2002) sosialisasi konsumen dipengaruhi oleh perkembangan kognitif mengenai tahapan berpikir anak sebagai interaksi antara kematangan diri secara biologis dan pengalaman dengan lingkungan. Orang tua, teman, dan media merupakan agen sosialisasi yang memiliki peran penting dalam perilaku makan remaja. Proses sosialisasi konsumen dimulai ketika anak dan orang dewasa saling berinteraksi dengan agen sosialisasi (Hota \& McGuiggan, 2005). Orang tua adalah agen sosialisasi yang penting untuk membantu remaja dalam membuat pilihan di masa yang akan datang (Daniloski, 2011). Penelitian sebelumnya menunjukan keterkaitan antara orang tua terhadap berat badan anak. Menurut Raiha et al. (2006) orang tua memiliki pengaruh positif dalam membentuk pola makan anak. Keterlibatan orang tua bagian komponen penting dalam pengendalian berat badan anak (Epstein et al., 1994).

Selain proses sosialisasi, di dalam keluarga juga berlangsung proses pembentukan kepribadian dan proses pengasuhan. Baumrind (1972) mengategorikan gaya pengasuhan menjadi tiga yaitu gaya pengasuhan otoriter, permisif, dan otoritatif. Pengategorian ini berdasarkan tingkat kehangatan dan kontrol kedisiplinan yang dipraktekan oleh orang tua. Gaya pengasuhan otoriter adalah gaya pengasuhan yang menekankan pada aturan dan batasan kepada anak. Gaya pengasuhan permisif adalah pengasuhan yang menerapkan sedikit pembatasan dan cenderung memberikan kebebasan. Gaya pengasuhan otoritatif adalah pengasuhan yang menggabungkan dua pendekatan, yaitu orang tua yang memberikan batasan aturan dan memiliki otoritas tinggi, tetapi juga orang tua yang hangat, penuh kasih sayang, memberikan penjelasan dan keterangan yang sesuai dengan pola pikir anak, toleran, dan empati kepada anak. Menurut Kremes et al. (2003), gaya pengasuhan otoritatif cenderung berdampak pada anak yang mengonsumsi buah lebih banyak dibandingkan dengan gaya pengasuhan lainnya. Orang tua yang menerapkan memilih gaya pengasuhan permisif cenderung membiarkan anak makan apa yang mereka inginkan (Nicklas et al., 2001), sedangkan orang tua otoriter cenderung mengontrol asupan dan praktik makan anak.
Gaya pengasuhan orang tua memiliki pengaruh langsung terhadap hasil sosialisasi anak melalui praktik pengasuhan. Orang tua memiliki peran yang sangat penting dalam sosialisasi makanan (Benton, 2004) dan memberikan pengalaman pertama mengenai makanan pada anak (Scaglioni et al., 2008). Orang tua menurunkan perilaku makan kepada anak melalui beberapa cara yaitu gaya pengasuhan dan komunikasi dalam keluarga. Orang tua yang menerapkan gaya pengasuhan otoritatif dan pola komunikasi conversation orientation cenderung menghasilkan anak yang mengonsumsi makanan sehat (Daniloski, 2011).

Selain gaya pengasuhan, komunikasi dalam keluarga berperan sangat penting sebagai alat untuk mentransfer nilai-nilai yang dianut dalam keluarga. Komunikasi berjalan secara bergantian dari orang tua ke anak atau dari anak ke orang tua. McLeod dan Chaffe (1972) membagi dua kategori pola komunikasi dalam keluarga yaitu conversation orientation dan conformity orientation. Koerner dan Fitzpatrick (2002) menyatakan bahwa conversation orientation adalah komunikasi dalam keluarga yang ditandai dengan setiap anggota keluarga bebas dan terbuka dalam mengemukakan pendapat dan ide, serta keputusan dalam keluarga diputuskan secara bersama. Conformity orientation adalah komunikasi dalam keluarga yang ditandai dengan kepatuhan anak terhadap orang tua dan pengambilan keputusan berada pada orang tua. Hasil penelitian John (1999) menemukan bahwa komunikasi orang tua dan anak memiliki pengaruh yang signifikan terhadap sosialisasi anak sebagai konsumen. Orang tua yang memenuhi keinginan anak akan mendorong anak untuk perhatian terhadap iklan, sedangkan orang tua yang mendiskusikan permintaan anak akan mendorong anak untuk mengembangkan keterampilan dalam memilih dan menginterpretasi informasi mengenai produk (Ward et al., 1990).

Selain pengaruh orang tua, teman dan media juga berperan dalam pemilihan makan remaja. Hal ini dikarenakan remaja cenderung beraktifitas di luar rumah dan lebih banyak menghabiskan waktu berinteraksi dengan media maupun menghabiskan waktu bersama teman. Media massa memiliki pengaruh untuk mengembangkan motivasi sosial dan keinginan dalam mengonsumsi suatu produk serta preferensi suatu merek. Anak yang banyak menghabiskan waktu untuk menonton televisi cenderung akan mengonsumsi 
makanan yang tidak sehat karena iklan yang ditampilkan mayoritas mengenai makanan yang tidak sesuai dengan pola makan sehat atau junk food. Menurut penelitian Tarabashkina (2013), remaja yang menghabiskan waktu menonton TV cenderung memperlihatkan motivasi sosial yang tinggi terhadap konsumsi, menggambarkan pengetahuan tentang produk, dan simbol sosial. Selain itu, teman juga merupakan sumber referensi bagi individu dalam proses pengambilan keputusan termasuk dalam memilih makanan, sedangkan media merupakan sumber informasi bagi konsumen dalam membandingkan produk dan membantu mempercepat proses pengambilan keputusan. Teman menjadi salah satu yang menentukan keputusan dalam memilih makanan. Hal ini terjadi karena mahasiswa menghabiskan sebagian besar waktunya bersama teman dan makan merupakan bagian penting dalam proses sosialisasi (Cutler et al., 2011).

Dalam penelitian ini, faktor orang tua diukur dari gaya pengasuhan yang diterima mahasiswa dari kecil dari orang tuanya dan juga komunikasi yang terjalin antara orang tua dengan mahasiswa. Sementara itu, faktor media dan teman diukur dari paparan informasi yang diperoleh mahasiswa dari media dan teman. Berdasarkan uraian tersebut, tujuan penelitian ini adalah: mengetahui kebiasaan makan sayur pada mahasiswa, mengidentifikasi karakteristik mahasiswa, karakteristik keluarga, gaya pengasuhan, pola komunikasi keluarga, paparan informasi dari media dan teman, serta pemilihan makanan khususnya sayur, dan menganalisis pengaruh gaya pengasuhan, pola komunikasi keluarga, paparan informasi dari media dan teman terhadap pemilihan makanan khususnya sayur.

\section{METODE}

Penelitian ini menggunakan desain cross sectional study, yang dilakukan dalam satu waktu tertentu dengan menggunakan metode survey kuantitatif. Penelitian ini melibatkan mahasiswa tingkat pertama yang tinggal di asrama. Hal ini ditetapkan secara purposive karena mahasiswa tingkat pertama masih dalam tahap beradaptasi dengan lingkungan asrama dan perilaku makan kemungkinan masih dipengaruhi oleh kebiasaan makan ketika bersama orang tua. Penelitian dilakukan pada bulan Februari hingga Juli 2016.

Populasi dalam penelitian ini adalah mahasiswa tingkat pertama di IPB yang tercatat sebagai mahasiswa pada Tahun Akademik 2015/2016 yang berjumlah 3.573 orang dan terdiri dari 33 kelas. Selanjutnya, contoh penelitian dipilih secara cluster random sampling dan terpilih tiga kelas yaitu P09, Q03, dan R02. Penelitian ini melibatkan 288 mahasiswa yang memenuhi kriteria diasuh oleh orang tua hingga berusia 16 tahun. Alasan pemilihan responden karena mahasiswa berada pada kategori remaja akhir dan dewasa awal yaitu berusia 17-21 tahun dan berasal dari berbagai daerah di Indonesia dengan berbagai latar belakang ekonomi, sehingga mahasiswa tingkat pertama di IPB dinilai merepresentasikan remaja dari berbagai wilayah di Indonesia.

Data primer diperoleh langsung dari mahasiswa yang meliputi karakteristik mahasiswa, karakteristik keluarga, gaya pengasuhan, pola komunikasi keluarga, paparan informasi melalui media dan teman, dan pemilihan makanan. Data dikumpulkan dengan cara self-administered menggunakan kuesioner yaitu mahasiswa mengisi sendiri kuesioner yang telah dibagikan, namun sebelumnya telah diberikan arahan mengenai cara pengisian yang bertujuan agar mahasiswa memahami kuesioner dengan baik.

Pengolahan data dilakukan dengan menggunakan program Microsoft Office Excel dan Statistical Package for the Social Sciences (SPSS). Data dan informasi yang diperoleh selanjutnya dianalisis dengan menggunakan analisis deskriptif, uji beda, dan uji regresi linear berganda. Instrumen gaya pengasuhan menggunakan gaya pengasuhan Baumrind yang terdiri dari gaya pengasuhan tipe otoritatif, otoriter, dan permissif yang diadopsi dari Robinson et al. (1995) dan telah dimodifikasi berdasarkan persepsi mahasiswa. Instrumen ini terdiri dari 30 pernyataan dengan nilai Cronbach's alpha 0,701. Pola komunikasi keluarga menggunakan instrumen Family Communication Pattern yang diadopsi dari Chaffe et al. (1972) dan telah dimodifikasi sesuai dengan topik dalam penelitian tentang konsumsi sayur. Pola komunikasi dibagi menjadi dua dimensi yaitu conversation orientation dan conformity orientation. Instrumen Family Communication Pattern ini terdiri dari 26 pernyataan dengan nilai Cronbach's alpha 0,660. Instrumen untuk mengukur paparan informasi dari media dan teman diadopsi dari Yuliati et al., (2012). Instrumen paparan informasi dari media mempunyai nilai Cronbach's alpha sebesar 0,829 yang terdiri dari lima pernyataan, sedangkan instrumen paparan informasi dari 
teman mempunyai nilai Cronbach's alpha 0,882 yang terdiri dari lima pernyataan. Pemilihan makanan menggunakan instrumen Food Choice Questionnaire yang diadopsi dari Steptoe et al. (1995) dan terdiri dari 26 pernyataan dengan nilai Cronbach's alpha 0,948 . Instrumen ini terdiri dari alasan kesehatan, suasana hati, kemudahan, sensorik, kandungan alami dalam pangan, harga, pengendalian berat badan, familiaritas, dan masalah etika. Sementara itu, konsumsi sayur mahasiswa juga dilihat dari frekuensi makan sayur yang diukur dengan menggunakan instrumen Food Frequency Questionnaire dari Eertmans (2006) yang terdiri dari empat pernyataan terbuka dan tertutup. Variabel dalam penelitian diukur dengan menggunakan skala Likert 1 sampai 5 yang menjelaskan bahwa $1=$ sangat tidak setuju, 2=tidak setuju, 3=netral, 4=setuju, dan $5=$ sangat setuju.

Pengolahan data dilakukan setelah data terkumpul mencakup penyuntingan data (editing), pemberian kode (coding), pemberian nilai (scoring), entry data, cleaning data dan analisis data. Dimensi persepsi gaya pengasuhan diukur melalui skor indeks tertinggi yang mencerminkan kecenderungan gaya pengasuhan yang dilakukan orang tua menurut persepsi mahasiswa. Dimensi pola komunikasi keluarga juga diukur melalui skor indeks tertinggi dari dua pola komunikasi yang mencerminkan kecenderungan komunikasi dalam keluarga yaitu conversation orientation dan conformity orientation. Paparan informasi media dan teman dinilai melalui rata-rata indeks skor tertinggi paparan informasi. Uji beda digunakan untuk menganalisis perbedaan antara mahasiswa berjenis kelamin laki-laki dan perempuan dengan menggunakan independent sample $t$-test. Uji pengaruh untuk menganalisis pengaruh variabel bebas terhadap variabel terikat dengan menggunakan analisis linier berganda.

\section{HASIL}

\section{Karakteristik Mahasiswa}

Hasil penelitian menemukan bahwa proporsi mahasiswa perempuan dan laki-laki yang menjadi partisipan penelitian ini masingmasing adalah 58,0 persen dan sebanyak 42,0 persen. Hasil penelitian ini menemukan bahwa sebanyak 44 persen mahasiswa berasal dari Jawa Barat dan sebanyak 66,0 persen berasal dari luar Jawa Barat. Uang saku bulanan mahasiswa berasal dari orang tua, beasiswa, dan bekerja. Mayoritas uang saku bulanan mahasiswa berasal dari orang tua yang sebagian besar bekerja sebagai PNS, swasta, dan wirausaha. Sementara itu, lebih dari setengah proporsi mahasiswa (56,6\%) mempunyai uang saku yang berada pada kisaran Rp600.000,00 sampai Rp1.000.000,00 dengan rata-rata uang saku sebesar Rp1.120.000,00 per bulan. Hasil penelitian menemukan adanya perbedaan nyata uang saku antara mahasiswa laki-laki dan perempuan yang mana mahasiswa perempuan memiliki uang saku lebih besar dibandingkan laki-laki.

\section{Karakteristik Keluarga}

Hasil penelitian menemukan bahwa lebih dari setengah mahasiswa $(52,1 \%)$ berada pada kategori keluarga sedang yaitu jumlah anggota keluarga sebanyak lima hingga tujuh orang. Usia orang tua mahasiswa dibagi menjadi lima kategori yaitu dewasa awal (19-24 tahun), dewasa madya (25-35 tahun), separuh baya (36-50 tahun), tua (51-65 tahun), dan lanjut usia (>65 tahun). Proporsi terbesar usia ayah mahasiswa laki-laki berada pada kategori usia tua $(56,0 \%)$, sedangkan proporsi terbesar usia ayah pada mahasiswa perempuan berada pada kategori separuh baya $(53,5 \%)$. Sementara itu, sekitar tiga dari empat $(78,4 \%)$ mempunyai ibu yang berada pada kategori usia separuh baya.

Selanjutnya, hasil penelitian juga menemukan bahwa sekitar satu dari tiga orang tua $(33,7 \%)$ telah menempuh pendidikan sampai jenjang SMA. Hasil juga menemukan adanya perbedaan nyata pada tingkat pendidikan ayah antara mahasiswa laki-laki dan perempuan. Ayah dari mahasiswa laki-laki memiliki pendidikan yang lebih tinggi dibandingkan mahasiswa perempuan. Hasil penelitan selanjutnya juga menemukan bahwa sebanyak 95,6 persen ayah mahasiswa bekerja sebagai PNS, swasta, dan wirausaha, sedangkan satu dari dua ibu mahasiswa $(53,2 \%)$ berstatus tidak bekerja. Pendapatan orang tua berada pada rentang Rp0 sampai Rp44.000.000,00 dengan rata-rata sebesar Rp5.740.000,00 per bulan. Hasil penelitian menemukan bahwa lebih dari separuh orang tua $(58,0 \%)$ mempunyai pendapatan yang berada pada kisaran Rp1.000.000,00 sampai Rp5.000.000,00 per bulan.

\section{Kebiasaan Makan Sayur}

Kebiasaan makan adalah pola perilaku konsumsi pangan yang terjadi secara berulang. Tabel 1 menunjukan bahwa terdapat 
perubahan kebiasaan makan mahasiswa sebelum dan setelah masuk IPB. Sebelum masuk IPB, mahasiswa laki-laki (48,8\%) cenderung makan sayur dengan porsi setengah mangkok, sedangkan pada mahasiswa perempuan (46,7\%) makan sayur dengan porsi satu mangkok. Namun setelah masuk IPB, mahasiswa laki-laki $(67,8 \%)$ dan perempuan $(73,1 \%)$ terbiasa makan sayur dengan porsi setengah mangkok. Frekuensi makan sayur pada mahasiswa laki-laki $(52,1 \%)$ dan perempuan $(60,5 \%)$ sebelum masuk IPB adalah lebih dari dua kali setiap hari, namun setelah masuk IPB pada mahasiswa laki-laki $(38,0 \%)$ dan perempuan $(37,2 \%)$ terbiasa makan sayur hanya sebanyak satu kali setiap hari. Jenis sayur yang dikonsumsi oleh mahasiswa laki-laki dan perempuan tidak mengalami perubahan antara sebelum dan setelah masuk IPB. Hal ini dapat dilihat bahwa mahasiswa cenderung terbiasa mengonsumsi sayur yang ditumis. Perubahan jumlah dan frekuensi makan sayur pada mahasiswa terjadi karena jenis sayur yang disediakan oleh kantin di sekitar asrama kurang beragam dan jenis sayur yang tersedia tidak biasa dikonsumsi oleh mahasiswa. Selain itu, rasa yang tidak sesuai dengan sayur yang dikonsumsi di rumah dapat menjadi penyebab perubahan kebiasaan makan sayur. Perubahan kebiasan mahasiswa dalam konsumsi sayur juga disebabkan oleh harga. Harga yang relatif mahal juga dapat memicu perubahan kebiasaan makan sehingga mahasiswa cenderung memilih mengonsumsi makanan lain seperti tahu, tempe, atau telur.

Tabel 1 Sebaran mahasiswa berdasarkan jumlah, frekuensi, dan jenis sayur yang dikonsumsi sebelum dan setelah masuk IPB

\begin{tabular}{|c|c|c|c|c|}
\hline \multirow{2}{*}{ Kategori } & \multicolumn{2}{|c|}{$\begin{array}{c}\text { Sebelum masuk } \\
\text { IPB }\end{array}$} & \multicolumn{2}{|c|}{$\begin{array}{c}\text { Setelah masuk } \\
\text { IPB }\end{array}$} \\
\hline & $\mathrm{L}(\%)$ & $\mathrm{P}(\%)$ & $\mathrm{L}(\%)$ & $\mathrm{P}(\%)$ \\
\hline \multicolumn{5}{|c|}{ Jumlah konsumsi } \\
\hline $1 / 2$ mangkok & 48,8 & 36,5 & 67,8 & 73,1 \\
\hline 1 mangkok & 40,5 & 46,7 & 25,6 & 23,4 \\
\hline $\begin{array}{ll}\geq 1 & 1 / 2 \\
\text { mangkok } & \end{array}$ & 10,7 & 16,8 & 6,6 & 3,6 \\
\hline Frekuensi/hari & & & & \\
\hline $\begin{array}{l}\text { Jarang/ tidak } \\
\text { pernah }\end{array}$ & 9,9 & 13,8 & 24,8 & 38,3 \\
\hline 1 kali & 38,0 & 25,7 & 38,0 & 40,7 \\
\hline$\geq 2$ kali & 52,1 & 60,5 & 37,2 & 21,0 \\
\hline \multicolumn{5}{|l|}{ Jenis sayur } \\
\hline $\begin{array}{l}\text { Sayur yang } \\
\text { ditumis }\end{array}$ & 56,2 & 56,3 & 60,0 & 55,1 \\
\hline Sayur mentah & 9,1 & 7,2 & 11,7 & 9,0 \\
\hline $\begin{array}{l}\text { Sayur } \\
\text { berkuah }\end{array}$ & 34,7 & 36,5 & 28,3 & 35,9 \\
\hline
\end{tabular}

\section{Gaya Pengasuhan}

Hasil penelitian ini menunjukan bahwa hampir seluruh mahasiswa $(93,8 \%)$, baik mahasiswa laki-laki maupun perempuan, mempunyai gaya pengasuhan otoritatif yang diterapkan oleh orang tua. Sementara itu, sebanyak 4,8 persen mahasiswa diasuh dengan gaya pengasuhan otoriter dan hanya 1,4 persen mahasiswa diasuh dengan gaya pengasuhan permisif. Hasil penelitian tidak menemukan adanya perbedaan signifikan pada gaya pengasuhan yang diterapkan orang tua antara mahasiswa laki-laki dan perempuan. Hal ini menjelaskan bahwa mayoritas orang tua mahasiswa menerapkan gaya pengasuhan otoritatif dan tidak membedakan gaya pengasuhan antara anak laki-laki dan perempuan.

\section{Pola Komunikasi Keluarga}

Hasil penelitian ini juga menemukan bahwa sekitar empat dari lima mahasiswa $(82,6 \%)$ mempunyai tipe pola komunikasi conversation orientation dan hanya 17,4 persen mahasiswa dengan pola komunikasi conformity orientation dalam berkomunikasi dengan orang tuanya. Hal ini menunjukkan bahwa pola komunikasi sebagian besar keluarga mahasiswa dalam penelitian ini adalah komunikasi yang bebas dan terbuka untuk mengemukakan pendapat, ide, perasaan, dan pengalaman satu sama lain dan keputusan keluarga diputuskan secara bersama-sama. Hasil penelitian menemukan terdapat perbedaan nyata pola komunikasi keluarga antara mahasiswa laki-laki dan perempuan. Hasil penelitian ini menerangkan bahwa perempuan cenderung memiliki pola komunikasi conversation orientation, dikarenakan perempuan cenderung dapat mengungkapkan perasaan dan pendapat terhadap keluarga dibandingkan laki-laki.

\section{Media dan Teman}

Selanjutnya, hasil penelitian juga menemukan bahwa mahasiswa laki-laki dan perempuan cenderung terpapar informasi melalui media dibandingkan oleh teman. Hasil uji beda tidak menemukan adanya perbedaan paparan informasi melalui media dan teman antara mahasiswa laki-laki dan perempuan. Iklan makanan memiliki potensi untuk menyampaikan pengaruh yang kuat dalam konsumsi makanan. Pesan yang ditampilkan melalui media elektronik maupun cetak sering memengaruhi konsumsi makanan. Mahasiswa yang banyak menghabiskan waktu menonton TV cenderung akan memperlihatkan motivasi sosial yang tinggi terhadap konsumsi, dan 
memiliki pengetahuan tentang produk suatu makanan. Hasil penelitian ini memperlihatkan bahwa tidak terdapat perbedaan paparan informasi melalui teman antara mahasiswa laki-laki dan perempuan. Teman memiliki pengaruh terhadap pemilihan makanan yang berakhir pada konsumsi makanan. Kurangnya pengaruh teman dalam pemilihan makan sayur pada mahasiswa yang ditemukan dalam peneltian ini dapat terjadi karena karakteristik mahasiswa yang berusia 17 hingga 21 tahun sudah terbiasa untuk menentukan makanan sendiri.

\section{Pemilihan Makanan}

Hasil penelitian menunjukan bahwa terdapat tiga alasan utama dalam pemilihan makanan khususnya sayur pada mahasiswa yaitu kesehatan, suasana hati, dan pengendalian berat badan. Pertama, mahasiswa memilih makan sayur dengan alasan kesehatan karena mengandung vitamin dan mineral, dapat menjaga kesehatan tubuh, bergizi, tinggi protein, baik untuk pencernaan, dan tinggi serat. Kedua, mahasiswa laki-laki dan perempuan memiliki kecenderungan mementingkan alasan suasana hati dengan pertimbangan dapat menjadikan tubuh lebih sehat, menyadarkan tentang pola hidup sehat, dapat meredakan stres, dan membuat tubuh merasa lebih baik. Ketiga, alasan pengendalian berat badan dengan pertimbangan rendah kalori, dapat membantu mengontrol berat badan, dan rendah lemak (Tabel 2).

Selain tiga alasan di atas, terdapat beberapa alasan dalam pemilihan makanan yaitu kemudahan, sensorik, kandungan alami dalam pangan, harga, familiaritas, dan masalah etika. Alasan kemudahan dalam penelitian ini diukur dalam aspek mudah dalam menyiapkan makanan (sayur), mudah dimasak, dapat dibeli di warung makan sekitar asrama, dan banyak tersedia di warung makan sekitar kampus.
Hasil penelitian menemukan bahwa baik mahasiswa laki-laki maupun perempuan cukup mementingkan alasan kemudahan karena dapat diperoleh dengan mudah di warungwarung sekitar kampus dan asrama. Sementara itu, alasan sensorik diukur dengan mempertimbangkan aroma yang enak, terlihat menarik, tekstur yang lembut, dan rasa yang enak. Pada mahasiswa laki-laki dan perempuan dalam penelitian ini, alasan ini cukup penting karena makanan yang memiliki aroma enak dan tampilan menarik akan mendorong seseorang untuk mencoba dan mengonsumsi makanan khususnya sayur. Alasan kandungan alami dalam pangan dengan mempertimbangkan komposisi makanan yang terdiri dari olahan sayur yang mengandung bahan alami dan tidak mengandung bahan kimia berbahaya, serta tidak mengandung bahan buatan. Hasil penelitian menunjukan bahwa mahasiswa cukup mementingkan alasan ini dalam pemilihan makanan. Mahasiswa yang memperhatikan kandungan alami dalam pangan cenderung menerapkan konsumsi makan sehat seperti sayur. Alasan harga dalam pemilihan makanan terdiri dari pertimbangan murah dan harga yang terjangkau. Harga sayur di warung makan sekitar kampus dijual dengan harga Rp2.000,00 hingga Rp4.000,00 per porsi setara dengan setengah mangkok. Harga tersebut dapat dijangkau oleh mahasiswa dengan uang saku rata-rata $\mathrm{Rp} 1.120 .000,00$ setiap bulan.

Penelitian menemukan adanya perbedaan nyata dalam hal alasan harga dalam pemilihan makanan khususnya sayur antara mahasiswa laki-laki dan mahasiswa perempuan. Mahasiswa laki-laki lebih mementingkan alasan harga dalam memilih makanan dengan mempertimbangkan harga murah dan terjangkau dibandingkan mahasiswa perempuan.

Tabel 2 Rataan capaian indeks alasan pemilihan makanan berdasarkan jenis kelamin

\begin{tabular}{lcccc}
\hline \multicolumn{1}{c}{ Alasan pemilihan } & \multicolumn{3}{c}{ Rata-rata indeks } & \multirow{2}{*}{$p$-value } \\
\cline { 2 - 4 } \multicolumn{1}{c}{ makanan } & Laki-laki & Perempuan & Total & 0,651 \\
Kesehatan & $74,5 \pm 17,4$ & $75,4 \pm 17,8$ & $75,0 \pm 17,6$ & 0,871 \\
Suasana hati & $66,6 \pm 18,0$ & $66,3 \pm 17,8$ & $66,4 \pm 17,9$ & 0,412 \\
Kemudahan & $56,5 \pm 14,0$ & $55,1 \pm 15,3$ & $55,7 \pm 14,7$ & 0,546 \\
Sensorik & $59,7 \pm 18,3$ & $58,3 \pm 19,6$ & $58,9 \pm 19,0$ & 0,573 \\
Kandungan alami dalam & $57,6 \pm 22,4$ & $56,0 \pm 23,5$ & $56,7 \pm 23,0$ & $0,029^{*}$ \\
pangan & $62,0 \pm 20,1$ & $56,7 \pm 20,7$ & $58,9 \pm 20,6$ & 0,252 \\
Harga & $64,5 \pm 18,5$ & $67,1 \pm 19,1$ & $66,0 \pm 18,8$ & 0,896 \\
Pengendalian berat & $64,2 \pm 19,6$ & $64,5 \pm 20,4$ & $64,4 \pm 20,1$ & 0,203 \\
badan & $61,6 \pm 17,3$ & $59,0 \pm 16,9$ & $60,1 \pm 17,1$ & \\
Familiaritas & & &
\end{tabular}

Keterangan : ${ }^{*}=$ signifikan pada level 0,05 
Alasan familiaritas meliputi makanan yang sering di konsumsi pada waktu kecil, makanan yang tidak asing bagi mahasiswa, dan biasa dikonsumsi. Kebiasaan mengonsumsi makanan didorong oleh ketersediaan makanan yang disiapkan oleh orang tua di rumah. Pada alasan ini, mahasiswa laki-laki dan perempuan juga memiliki kecenderungan mementingkan alasan familiaritas dalam memilih makanan. Hal ini menunjukan bahwa mahasiswa laki-laki dan perempuan cenderung memilih dan mengonsumsi makanan yang biasa dikonsumsi sejak kecil. Alasan etika dalam pemilihan makanan meliputi sayur yang berasal dari petani Indonesia dan dikemas dengan ramah lingkungan. Hasil penelitian menemukan bahwa mahasiswa laki-laki lebih mementingkan alasan ini dibandingkan perempuan. Hal ini menunjukan bahwa lakilaki lebih memahami dan peduli terhadap makanan yang ramah lingkungan dan berasal dari petani lokal.

\section{Pengaruh Gaya Pengasuhan, Pola Komunikasi Keluarga, dan Paparan Informasi Media dan Teman terhadap Pemilihan Makanan}

Hasil analisis regresi linear berganda menerangkan bahwa variabel independen (jenis kelamin, uang saku, usia ayah dan ibu, pendidikan ibu, gaya pengasuhan otoritatif, otoriter, permissif, pola komunikasi conversation orientatin, conformity orientation, paparan informasi dari media, dan paparan informasi dari teman) memiliki pengaruh terhadap pemilihan makan sayur sebesar 26,4 persen (Tabel 3) dan sisanya sebesar 73,6 persen dipengaruhi oleh variabel lain yang tidak diteliti.

Jenis kelamin memiliki pengaruh negatif signifikan terhadap pemilihan makanan sebesar 29,64 persen $(\beta=-2,964 ; p<0,05)$. Artinya, mahasiswa laki-laki cenderung lebih memilih makan sayur dibandingkan perempuan. Selanjunya, gaya pengasuhan otoritatif memiliki pengaruh positif sangat signifikan terhadap pemilihan makanan sebesar 22,7 persen $(\beta=0,227 ; \quad p<0,01)$. Sementara itu, paparan informasi dari media memiliki pengaruh positif sangat signifikan terhadap pemilihan makanan sehat sebesar 34 persen $(\beta=0,340 ; p<0,01)$. Hal ini menunjukkan bahwa semakin optimal gaya pengasuhan otoritatif yang dilakukan orang tua dan peningkatan paparan informasi dari media yang diperoleh mahasiswa menyebabkan peningkatan dan mengoptimalkan kebiasaan mahasiswa dalam konsumsi sayur.
Tabel 3 Hasil analisis regresi berganda antara karakteristik mahasiswa, karakteristik keluarga, gaya pengasuhan, pola komunikasi, media dan teman terhadap pemilihan makan

\begin{tabular}{|c|c|c|c|}
\hline \multirow{2}{*}{ Variabel } & \multicolumn{3}{|c|}{ Pemilihan makanan } \\
\hline & B & $\beta$ & Sig. \\
\hline Konstanta & 16,441 & & 0,110 \\
\hline $\begin{array}{l}\text { Jenis kelamin }(0=\text { laki- } \\
\text { laki; } 1=\text { perempuan) }\end{array}$ & $-2,964$ & 1,462 & $0,044^{*}$ \\
\hline $\begin{array}{l}\text { Uang saku } \\
\text { (rupiah/bulan) }\end{array}$ & $-0,010$ & $\overline{0}, 040$ & 0,456 \\
\hline Usia ayah (tahun) & $-0,016$ & 0,166 & 0,921 \\
\hline Usia ibu (tahun) & 0,335 & 0,179 & 0,063 \\
\hline Pendidikan ibu & 0,260 & 0,493 & 0,599 \\
\hline $\begin{array}{l}\text { Gaya pengasuhan } \\
\text { otoritatif }\end{array}$ & 0,227 & 0,077 & $0,003^{* *}$ \\
\hline $\begin{array}{l}\text { Gaya pengasuhan } \\
\text { otoriter }\end{array}$ & $-0,027$ & 0,085 & 0,749 \\
\hline $\begin{array}{l}\text { Gaya pengasuhan } \\
\text { permissif }\end{array}$ & $-0,035$ & 0,052 & 0,502 \\
\hline $\begin{array}{l}\text { Pola komunikasi } \\
\text { conversation }\end{array}$ & 0,011 & 0,085 & 0,898 \\
\hline $\begin{array}{l}\text { Pola komunikasi } \\
\text { conformity }\end{array}$ & 0,010 & 0,067 & 0,877 \\
\hline $\begin{array}{l}\text { Paparan informasi dari } \\
\text { media }\end{array}$ & 0,340 & 0,047 & $0,000^{* *}$ \\
\hline $\begin{array}{l}\text { Paparan informasi dari } \\
\text { teman }\end{array}$ & $-0,003$ & 0,041 & 0,950 \\
\hline Uji F & & & 8,331 \\
\hline $\mathrm{Sig}$ & & & $0,000^{* *}$ \\
\hline$R$ Square & & & 0,300 \\
\hline Adjusted $R$ Square & & & 0,264 \\
\hline
\end{tabular}

\section{PEMBAHASAN}

Hasil penelitian ini menunjukan tiga alasan utama dalam pemilihan makanan yaitu kesehatan, suasana hati, dan pengendalian berat badan. Hal ini didukung oleh hasil penelitian Sun (2008) yang menemukan bahwa alasan utama pemilihan makanan pada seseorang dengan rata-rata usia 21 tahun adalah harga, sensorik, dan suasana hati. Menurut Steptoe et al. (1995) menyatakan bahwa alasan sensorik, harga, dan kesehatan menjadi alasan utama dalam pemilihan pangan pada usia 17-89 tahun. Hasil penelitian menemukan bahwa mahasiswa laki-laki cenderung memilih makan sayur dengan alasan harga murah dan terjangkau. Hasil ini sejalan dengan penelitian Missagia et al. (2012) yang menemukan bahwa laki-laki lebih memilih makanan dengan harga murah namun tidak bersedia menghabiskan waktu untuk membandingkan harga produk makanan, sebaliknya perempuan lebih banyak menghabiskan waktu untuk membandingkan harga sebelum membeli produk makanan. 
Hasil penelitian juga menemukan bahwa mahasiswa yang berasal dari Jawa Barat cenderung memilih makanan yang tidak asing baginya dan sering dikonsumsi sejak kecil. Seseorang akan cenderung memilih makanan yang sudah biasa dimakan dibandingkan mengambil resiko untuk mencoba makanan yang baru (Steptoe et al., 1995). Selain itu, mahasiswa yang memiliki uang saku setiap bulan di atas rata-rata cenderung tidak memperhatikan harga yang murah dan terjangkau dalam memilih makan sayur. Uang saku yang besar akan mendorong seseorang untuk memilih makanan yang modern dengan pertimbangan prestige dan harapan akan diterima oleh teman. Hal ini sejalan dengan hasil penelitian Biloukha (2000) bahwa harga makanan merupakan bagian paling penting dalam pemilihan makanan bagi seseorang dengan pendapatan rendah. Seseorang dengan keadaan ekonomi baik, cenderung mengesampingkan harga dalam pemilihan makanan karena adanya pertimbangan rasa dan kemudahan dalam penyiapan makanan. Wrieden (1996) menyatakan bahwa anak dari latar belakang sosial ekonomi tinggi mengonsumsi sayur dan kentang (bukan keripik kentang) lebih banyak dibandingkan anak dari latar belakang tidak makmur.

Hasil penelitian ini menerangkan bahwa pemilihan makan sayur dipengaruhi oleh dua variabel yaitu gaya pengasuhan otoritatif dan paparan informasi melalui media. Hal ini menunjukan bahwa mahasiswa dengan gaya pengasuhan otoritatif lebih memilih makan sayur dibandingkan mahasiswa dengan gaya pengasuhan otoriter dan permisif. Hasil ini juga sejalan dengan penelitian Kremes et al. (2003) yang menemukan bahwa anak dengan gaya pengasuhan otoritatif cenderung lebih banyak mengonsumsi sayur dan buah dibandingkan anak dengan pengasuhan yang lainnya. Hasil penelitian Patrick et al. (2005) menyatakan bahwa anak dengan gaya pengasuhan otoritatif lebih memperlihatkan peningkatan konsumsi harian dan konsumsi sayur karena orang tua lebih menyediakan buah-buahan dan sayur di rumah, serta lebih berupaya untuk memberikan buah dan sayur pada anak mereka.

Hasil penelitian ini menemukan bahwa paparan informasi dari media memiliki pengaruh sangat signifikan terhadap pemilihan makanan khususnya sayur pada mahasiswa dalam penelitian ini. Hal ini menunjukan bahwa mahasiswa yang terpapar informasi melalui media akan cenderung memilih makan sayur karena memiliki pengetahuan mengenai sayur.
Hal ini menjelaskan bahwa mahasiswa yang banyak terpapar informasi melalui media lebih memilih makan sayur karena mempertimbangkan berbagai alasan. Paparan informasi melalui media akan mendorong mahasiswa untuk mempertimbangkan alasan kesehatan, suasana hati, kemudahan, daya tarik sensorik, kandungan alami dalam pangan, harga, pengendalian berat badan, familiaritas, dan alasan masalah etika. Kebiasaan makan dan keputusan memilih makanan di kalangan remaja ternyata lebih kompleks dan dipengaruhi oleh banyak faktor seperti fisik, sosial, lingkungan budaya, pengaruh lingkungan sekitar (teman, keluarga, dan media) serta faktor psikososial (Robert \& Williams, 2000). Media massa, industri makanan, dan iklan khususnya iklan yang melalui media massa, seperti televisi dan majalah-majalah wanita akan mendukung masyarakat dalam pertimbangan pemilihan makanan. Khususnya pada anak-anak dan remaja, konsumsi makanan yang mengandung tinggi garam, gula, lemak, kalori, dan minuman berkarbonat sangat dipengaruhi oleh paparan iklan di media massa. Televisi mempunyai hubungan dengan peningkatan konsumsi makanan tinggi lemak, gula, garam dan minuman berkarbonat serta rendah serat, serta makanan yang ditayangkan lewat televisi beresiko memberi pengaruh pada perilaku makan anak (Maurer \& Smith, 2005)

Pemilihan makanan khususnya sayur dipengaruhi oleh beberapa faktor seperti faktor personal, faktor lingkungan, dan faktor makanan. Faktor lingkungan memengaruhi seseorang melalui interaksi secara langsung maupun melalui pemodelan. Interaksi dengan lingkungan sosial akan memberikan dampak pengetahuan mengenai suatu produk makanan. Menurut Hota dan McGuiggan (2005), tingkatan agen sosialisasi yang memengaruhi sosialisasi konsumen yaitu orang tua, media (televisi/iklan), dan teman. Media massa memengaruhi seseorang untuk mengembangkan pengetahuan dan motivasi untuk mengonsumsi makanan. Orang tua memengaruhi praktek makan anak melalui menyediakan makanan untuk dikonsumsi oleh anak dan memberikan pengetahuan tentang makanan ke anak. Orang tua dapat berfungsi sebagai panutan untuk perilaku makan anak, sikap terhadap makanan, dan preferensi makan (Rozin et al., 1984). Hal ini menunjukan bahwa pemilihan makanan setelah dewasa terus dipengaruhi oleh proses sosialisasi yang dimulai pada masa kanak-kanak dan orang tua sangat berperan dalam proses tersebut. 


\section{SIMPULAN DAN SARAN}

Proporsi jumlah mahasiswa perempuan yang terlibat sebagai partisipan penelitian ini lebih banyak dibandingkan mahasiswa laki-laki. Rata-rata uang saku mahasiswa dalam penelitian ini adalah sebesar Rp1.120.000,00 per bulan. Hasil penelitian menemukan bahwa lebih dari setengah mahasiswa berada pada kategori keluarga sedang yaitu jumlah anggota keluarga sebanyak lima hingga tujuh orang. Proporsi terbesar ayah mahasiswa laki-laki berada pada kategori usia tua, sedangkan ayah pada mahasiswa perempuan proporsi terbesarnya berada pada kategori separuh baya. Hasil juga menemukan bahwa lebih dari tiga perempat ibu mahasiswa berada pada kategori usia separuh baya. Selain itu, satu dari tiga mahasiswa memiliki orang tua yang telah menempuh pendidikan sampai jenjang SMA. Rata-rata pendapatan keluarga mahasiswa adalah sebesar Rp5.740.000,00 per bulan.

Hasil penelitian ini menunjukan bahwa terdapat perubahan jumlah dan frekuensi konsumsi sayur pada mahasiswa sebelum dan setelah masuk IPB. Hasil menemukan bahwa hampir seluruh mahasiswa mempunyai gaya pengasuhan otoritatif dari orang tuanya. Selain itu, lebih dari tiga perempat mahasiswa lakilaki dan perempuan mempunyai tipe pola komunikasi conversation orientation dengan orang tuanya. Mahasiswa laki-laki dan perempuan cenderung terpapar informasi melalui media dibandingkan oleh teman. Hasil penelitian mengidentifikasi tiga alasan utama dalam pemilihan makanan khususnya sayur pada mahasiswa yaitu kesehatan, suasana hati, dan pengendalian berat badan. Berdasarkan uji regresi linear berganda menunjukan bahwa pemilihan makan sayur pada mahasiswa dipengaruhi oleh gaya pengasuhan otoritatif yang diterima mahasiswa dari orang tuanya, paparan informasi dari media, dan jenis kelamin mahasiswa.

Penelitian selanjutnya diharapkan dapat menganalisis variabel pengetahuan terhadap pemilihan makanan, mengukur konsumsi sayur pada waktu dan situasi tertentu, serta mengukur pemilihan makanan berdasarkan faktor atribut makanan (rasa, warna, tekstur, bentuk). Bagi orang tua, sebagai agen penting dalam proses sosialisasi konsumen, hendaknya dapat memberikan pengetahuan dan informasi mengenai pemilihan makanan khususnya sayur dengan menerapkan gaya pengasuhan otoritatif yang memberikan pengetahuan dan informasi terkait manfaat mengonsumsi makanan sehat sejak dini. Bagi institusi pendidikan, hendaknya menyediakan kantin yang memiliki berbagai menu sayur sehingga dapat memberikan keleluasaan bagi mahasiswa untuk memilih sayur yang biasa mahasiswa konsumsi ketika di rumah. Bagi pemerintah khususnya Kementerian Kesehatan sebaiknya meningkatkan kepedulian terhadap konsumsi sayur pada remaja melalui berbagai program konsumsi sayur agar dapat meningkatkan kualitas kesehatan remaja di masa yang akan datang.

\section{DAFTAR PUSTAKA}

Baumrind, D. (1972). An exploratory study of socialization effects on Black children: Some Black-White comparisons. Child Development, 43, 261-267.

Benton, D. (2004). Role of parents in the determination of the food preferences of children and the development of obesity. International Journal of Obesity. 28: 858869.

Biloukha, Oleg, O., \& Utermohlen V. (2000). Correlates of food consumtion and perception of food in an educated urban population in Ukraine. Food Quality and Preference, 11, 475-485. Diambil dari http://www.sciencedirect.com/science/art icle/pii/S0950329300000203. [diunduh 25 Mei 2016].

Badan Ketahanan Pangan Daerah [BKPD]. (2015). Kontribusi sayur dalam pola pangan harapan keluarga Indonesia. [internet]. [diunduh pada 28 April 2016]. Tersedia pada: http://bkpd.jabarprov.go.id/kontribusisayur-dalam-pola-pangan-harapankeluarga-indonesia/

Cutler, G.J., Flood, A., Hannan, P.J., Slavin, J.L., Neumark-Sztainer, D. (2011). Association between major patterns of dietary intake and weight status in adolescents. British Journal of Nutrition. 13: $1-8$.

Daniloski, K. M. (2011). Adolescent Food Choice: Developing and Evaluating a Model of Parental Influence (Disertasi). University of. Faculty of Virginia

Eertmans, A. (2006). Sensory-affective and other determinant of food choice: their relative importance and variability across individualsand snd situations. (Disertasi) Chatolic University of Leuven, Leuven.

Elmanora, Muflikhati, I., Alfiasari. (2012). Gaya pengasuhan dan perkembangan sosial 
emosi anak usia sekolah pada keluarga petani kayu manis. Jurnal Ilmu Keluarga dan Konsumen. 5(2): 128-137

Epstein, L. H., Wisniewski, L., \& Weng, R. (1994). Child and parent psychological problem influence child weight control. 2(6), 509-515. Diambil dari http://onlinelibrary.wiley.com/doi/10.1002 i.1550-8528.1994.tb00099.x. [diunduh 25 Mei 2016].

Hadi, H. (2005). Beban ganda masalah kebijakan gizi dan implikasinya terhadap pembangunan kesehatan nasional. Pidato Jabatan Guru Besar Universitas Negeri Yogyakarta

Hawkins, D. I., Best, R. J., \& Coney, K. A. (2002). Consumer Behaviour: Building Marketing Strategy. New York: Tata McGraw Hill Companies. 212-215.

Hota, M., \& McGuiggan, R. (2005). The Relative Influence of Consumer Socialization Agents on Children and Adolescents - Examining the Past and Modeling the Future. [internet] diakses pada tanggal 15 Januari 2016 http://www.acrwebsite.org/volumes/1383 1/eacr/vol7/E-07

John, D. R. (1999). Consumer Socialization of Children: a retrospective look at twentyfive years of research. Journal of Consumer Research, 26(3), 183-213.

Koerner, A. F., \& Fitzpatrick, M. A. (2002). Understanding family communication patterns and family functioning: The roles of conversation orientation and conformity orientation. 26, 37-68.

Kremes, S. P. J., Bru, J., Vries de H., \& Engels, R. C. M. E. (2003). Parenting style and adolescents fruit consumtion. 43-50.

Lyte, L. A., Seifert, S., Greenstein, J., \& McGovern, P. (2000). How do children's eating patterns and food choices change over time? Results from a cohort study. American Journal of Health Promotion 14: 222-228.

Maurer, F.A., \& Smith, C.M. (2005). Community Public Health Nursing Practice : Health For Families And Populations. Third Edition

McLeod, J. M., \& Chaffee, S. H. (1972). The construction of social reality. In $\mathrm{J}$. Tedeschi. The social influence process, 50-59.

Missagia, S. V., Oliveira de R., \& Rezende de D. C. (2012). Food choice motives and healthy eating: Assessing gender differences. 22-26.

Mowen, J. C., \& Minor, M. (1998). Consumer Behaviour. Ed ke-5. New Jersey: Prentice Hall.

Nicklas, T. A., Baranowski, J.C., Cullen, K., Rittenberry, L., \& Olvera, N. (2001). Family and child-care provider influences on preschool children's fruit, juice, and vegetable consumption. 59, 224-235.

Pasaribu, R. M., Hastuti, D., \& Alfiasari. (2013). Gaya pengasuhan permisif dan rendahnya sosialisasi nilai dalam keluarga beresiko terhadap penurunan karakter remaja. Jur. IIm. Kel. \& Kons. 6 (3): 163-171.

Patrick, Heather, Theresa, A., Nicklas, Sheryl, O. H., \& Miriam, M. (2005). The Benefits of Authoritative Feeding Style: Caregiver Feeding Styles and Children's Food Consumption Patterns. 44(2), 243-49.

Perera, T., Madhujith, T. (2012). The Pattern of Consumption of Fruits and Vegetables by Undergraduate Students: A Case Study. 23(3), 261-271.

Raiha, T., Tossavainen, K., Turunen, H., Enkenberg, J., \& Halonen, P. (2006). Adolescent's nutrition health issues: opinion of Finnish seventh-graders. Health Education, 106(2), 114-132.

Ree, M., Riedger, N., \& Moghadasian, M. H. (2008). Factors affecting food selection in Canadian Population. Eur J Clin Nutr. 62(1):1255-1262.

Robert, B. S. W., \& Williams, S. R. (2000). Nutrition Throughout The Life Cycle. 4th Edition. The McGraw-Hill Book Companies :Inc. Singapore

Robinson, C., Mandleco, B., Olsen, S. F., \& Hart, C. H. (1995). Authoritative, authoritarian, and permissive parenting practices: development of a new measure. Psychological Report. 77, 819830.

Saufika, A., Retnaningsih, Alfiasari. (2012). Gaya hidup dan kebiasaan makan mahasiswa. Jurnal Ilmu Keluarga dan Konsumen, 5 (2):157-165

Scaglioni, S., Salvioni, M., \& Galimberti, C. (2008). Influence of parental attitudes in the development of children eating behavior. British Journal of Nutrition. 99: 22-25.

Septiani, I. A. P. (2014). Faktor-faktor yang berhubungan dengan pemilihan 
makanan pada siswa sekolah menengah atas di kota Yogyakarta. (Tesis]. UGM: Yogyakarta.

Sommer, I., MacKenzie, H., Venter, C., Dean, T. (2012). Factor influencing food choices of food-allergic consumers: findings from focus groups. 67: 13191322.

Steptoe, A., Pollard, T. M., \& Wardle, J. (1995). Development of a measure of the motives underlying the selection of food: the food choice questionnaire. 25, 267284.

Sumarwan, U. (2011). Perilaku Konsumen: Teori dan Penerapannya dalam Pemasaran. Ed ke-2. Bogor (ID): Ghalia Indonesia.

Sun, Y. C. (2008). Health concern, food choice motives, and atitudes toward healthy eating: the mediating role of food choice motives. 51(1):42-49.

Ward, S., Donna, M. K., \& Daniel, B. W. (1990). Consumer socialization reserach: Content analysis of post-1980 studies, and some implications for future work. Advances in Consumer Research, 17, 798-803.
Ward, S., Donna, M. K., \& Daniel, B. W. (1990). Consumer socialization reserach: Content analysis of post-1980 studies, and some implications for future work. Advances in Consumer Research. 17: 798-803

Wrieden, W. (1996). Fruit and vegetable consumption of 10-11 year old children in a region of Scotland. Health Education Journal, 14, 185-19.

Wrieden, W. (1996). Fruit and vegetable consumption of 10-11 year old children in a region of Scotland. Health Education Journal. 14: 185-19

Yuliati, L. N., Retnaningsih, \& Aprilia, D. (2012). Pengaruh kelompok acuan terhadap kesadaran dan konsumsi beras merah (Oryza nivara). Jur. IImu Keluarga dan Konsumen, 5(2), 166-174 